\title{
Communication works for those who work at it
}

\section{Craig French}

www.doi.org/10.51893/2020.4.e1

Published online 7 December 2020

The transition of a patient's care from active intensive care treatment to palliation is always sad and sometimes challenging. The decision is made when consensus of medical opinion is that ongoing life-sustaining therapies will not be effective - the acceptance of this medical decision is sought most often from a representative of the patient's family. This contrasts with the decision to provide consent for organ donation: in all Australian jurisdictions this is a decision made by the family not clinicians. It is essential that the information families require is communicated in a manner that helps them make a decision that is enduring and correct for them. While both types of conversations are considered difficult, the nature of the information provided is very different, and thus different communication strategies are required. Intensive care trainees undertake communication skills training and, as practising intensivists, will regularly use these skills to inform patients' families of the medical decision to transition to palliative care. ${ }^{1}$ Intensive care trainees also undertake training in communication skills to assist in the donation process. ${ }^{1}$ As practising intensivists, however, most will only infrequently raise and seek consent for organ donation from families.

In November 2008, then Prime Minister Kevin Rudd announced the establishment of the Australian Organ and Tissue Authority. ${ }^{2}$ The Authority was charged to implement a consistent and coordinated system of organ and tissue donation for transplantation; in a decade, the number of deceased donors increased from 247 in 2009 to 548 in 2019. ${ }^{3}$ The reasons for this increase are multifactorial and include strategies to raise community awareness and engagement together with structural changes to hospital and transplant sectors. A key element of the latter was the introduction of specialist medical and nursing organ donation practitioners into Australian hospitals. The impact of this strategy on the nature and outcomes of Australian organ donation conversations is uncertain. A small beforeand-after implementation study did not find any difference in consent rates with the presence of a designated requestor, ${ }^{4}$ and an observational study found that conversations led by a trained requestor, not part of the treating team, were associated with higher consent rates. ${ }^{5}$

The study reported by Radford and colleagues ${ }^{6}$ in this edition of the Journal addresses this paucity of local evidence.
All 1420 documented organ donation request conversations in the 2017 calendar were stratified into four groups by the potential donor's status on the Australian Organ Donor Register (yes, no or unknown) and who (clinician or family member) raised the topic of organ donation. The most common conversation type (>60\%) was where the donor's Register status was unknown and donation was raised by clinical staff. In such circumstances, families consented to organ donation significantly more often when the request was made by a specialist requestor - a clinician employed as a donation specialist. The observations in the other three groups are broadly consistent with this finding: more families provide consent for organ donation when the request comes from a specialist.

Is there a benefit for bereaved families to consenting to organ donation? The answer is yes. In Australia, nearly all donor families $(92 \%)$ find comfort in the donation of their loved one's organs. ${ }^{7}$ For these family members, donation has helped them in their grief (64\%) and provided meaning to them $(63 \%))^{7}$ If a family makes a decision that is not proactive and enduring because of the way information was communicated to them, then they are denied the potential to experience the comfort described by many donor families.

As a retrospective analysis, the report by Radford and colleagues ${ }^{6}$ has limitations. It does not report or adjust for many potential cofounders, such as donor characteristics, donation after brain or circulatory death, whether organ donation was raised by clinicians in a pre-formal approach, location of the request (intensive care unit, emergency department, or other), and the time of request. However, the association is relatively strong and consistent with the United Kingdom experience. ${ }^{8}$ Taken together, these studies indicate that it is highly likely more families provide consent for organ donation when the request comes from a donation specialist.

Our community has the right to expect that the information provided during organ donation conversations, together with the manner in which it is presented, helps family members to make the correct decision for them on behalf of their relative. Irrespective of the decision, this benefits both family members and the broader community. All intensivists have an essential role in the organ donation 


\section{EDITORIAL}

process, including the identification and management of potential donors, support of donor families and care of transplant recipients. In a 1995 survey of intensivists and trainees, over $70 \%$ of respondents believed that it was the role of the treating intensivist to request organ donation. ${ }^{9}$ Today, 25 years later, the response may be very different. It is perhaps time to accept that it is not possible for all intensivists to be organ donation requestors. These challenging conversations, in particular those where the potential donors register status is unknown, should be led by a highly trained specialist clinician who regularly undertakes them. As John Powell said, "Communication works for those who work at it".

\section{Competing interests}

None declared.

\section{Author details}

Craig French ${ }^{1,2,3}$

1 Department of Intensive Care Western Health, Melbourne, VIC, Australia.

2 Department of Medicine, University of Melbourne, Melbourne, VIC, Australia.

3 Australian and New Zealand Intensive Care Research Centre (ANZIC RC), Monash University, Melbourne, VIC, Australia.

Correspondence: Craig.French@wh.org.au

\section{References}

1 College of Intensive Care Medicine of Australia and New Zealand. Face to face courses [website]. https://cicm.org.au/Trainees/ Training-Courses/Face-to-Face-Courses (viewed Oct 2020).

2 Department of the Prime Minister and Cabinet. Donate Life launch [PM transcripts]. Canberra: Australian Government, 2008. https://pmtranscripts.pmc.gov.au/release/ transcript-16885 (viewed Oct 2020).

3 Organ and Tissue Authority. Facts and statistics [website]. https://donatelife.gov.au/about-donation/frequently-askedquestions/facts-and-statistics (viewed Oct 2020).

4 Potter JE, Perry L, Elliott RM, et al. Communication with Families Regarding Organ and Tissue Donation after Death in Intensive Care (COMFORT): a multicentre before-and-after study. Crit Care Resusc 2018; 20: 268-76.

5 Lewis VJ, White VM, Bell A, Mehakovic E. Towards a national model for organ donation requests in Australia: evaluation of a pilot model. Crit Care Resusc 2015; 17: 233-8.

6 Radford S, D'Costa R, Opdam H, et al. The impact of organ donation specialists on consent rate in challenging organ conversations. Crit Care Resusc 2020; 22: 297-302.

7 Organ and Tissue Authority. National Study of Family Experiences of Organ and Tissue Donation. Canberra: OTA, 2019. https://donatelife.gov.au/sites/default/files/national_ donor_family_study_wave_3_report.pdf (viewed Oct 2020).

8 Hulme W, Allen J, Manara AR, et al. Factors influencing the family consent rate for organ donation in the UK. Anaesthesia 2016; 71: 1053-63.

9 Pearson IY, Zurynski Y. A survey of personal and professional attitudes of intensivists to organ donation and transplantation. Anaesth Intensive Care 1995; 23: 68-74. 